\title{
Gminny podział administracyjny w świetle 25 lat funkcjonowania samorządu terytorialnego w Polsce
}

\begin{abstract}
Streszczenie: Artykuł przedstawia główne zmiany podziału terytorialnego Polski i ich ocenę na poziomie gminnym. Punktem odniesienia są reformy terytorialne w innych krajach UE, szczególnie tych, które podobnie jak Polska posiadają trójstopniową strukturę terytorialną. Podstawową tezą pracy jest stwierdzenie, że organizacja terytorialna administracji publicznej powinna zmieniać się w relacji do rozwoju procesów politycznych, gospodarczych, społecznych i co dla niej szczególnie istotne, także przestrzennych. Artykuł kończą rekomendacje związane z kierunkami przekształceń lokalnych struktur administracyjnych, takich jak łączenie (fuzje) gmin miejskich i wiejskich.
\end{abstract}

Słowa kluczowe: Polska, podział terytorialny, reforma administracyjna, gmina

\section{Wprowadzenie}

ednym z głównych celów transformacji systemowej w Polsce stała się decentralizacja władzy i administracji, urzeczywistniona w postaci restytucji samorządu terytorialnego i zmienionych ram terytorialnych jego działania. W 2015 roku minęło 25 lat od powołania instytucji samorządu terytorialnego na poziomie gminnym. Reforma zarządzania jednostkami lokalnymi stała się impulsem do dalszej decentralizacji dokonanej w 1998 r. na poziomie powiatowym i wojewódzkim. Te dwa etapy reform samorządowych zmieniły funkcjonowanie podziału administracyjnego kraju. Stał się on jednym z podstawowych atrybutów działania zdecentralizowanej administracji publicznej, stanowiąc jednocześnie, szczególnie na poziomie lokalnym, przestrzenne ramy funkcjonowania gospodarki, życia społecznego i aktywności obywatelskiej mieszkańców.

Wzrost wymagań wobec administracji publicznej rodzi konieczność stałego podnoszenia efektywności zarządzania publicznego, między innymi poprzez racjonalizację struktur terytorialnych, odpowiadających zmieniającym się układom przestrzenno-funkcjonalnym. Na kształtowanie podziału administracyjnego kraju wpływ mają rozmaite czynniki, zarówno wewnętrzne związane z przekształceniami demograficznymi, osadniczymi (rozwój przestrzenny, głównie dużych miast), jak i zewnętrzne, takie jak globalizacja gospodarki. Ich efektem jest zróżnicowana dynamika rozwoju demograficznego i społeczno-gospodarczego jednostek terytorialnych i związane z tym procesy dywergencji oraz konwergencji regionalnej, wspierane funduszami strukturalnym UE. Nic więc dziwnego, że z perspektywy czasu pojawiają się głosy odnoszące się do potrzeby korekt, a nawet reform organizacji terytorialnej Polski. Upodmiotowione społeczności jednostek terytorialnych coraz bardziej emanują poczuciem lokalizmu (lub regionali- 
zmu) oraz bronią prawa do samostanowienia, a te, które pozbawione są reprezentacji samorządowej, domagają się korekt podziału terytorialnego i uwzględnienia ich prawa do samorządności.

Podział administracyjny kraju doczekał się już wielu analiz i ocen w literaturze naukowej, zarówno w momencie jego zmian (m.in. Chojnicki, Czyż, 2000; Karliński, Nelicki, Płoskonka, 2000; Kaczmarek, 2001; Ocena nowego podziału ..., 2001; Miszczuk, 2003), jak i po dłuższym okresie funkcjonowania (m.in. Izdebski, 2009; Ustrój terytorialny państwa..., 2012; Walczak, 2012). Większość wyżej wymienionych prac zawiera potwierdzenie dyrektywy sformułowanej w art. 15 ust. 1. Konstytucji RP: „Ustrój terytorialny Rzeczypospolitej Polskiej zapewnia decentralizację władzy publicznej”. Jednocześnie jedna z konkluzji, jaką można sformułować na podstawie dotychczasowych ocen brzmi, że współczesny podział terytorialny Polski nie odpowiada w pełni potrzebom i wyzwaniom rozwoju kraju. Tym samym, zdaniem wielu autorów, nie stanowi optymalnej konstrukcji przestrzenno-funkcjonalnej, ocenianej pod kątem realizacji zadań terytorialnej administracji publicznej i imperatywu zapisanego w art. 15, ust. 2. Konstytucji RP o zdolności jednostek terytorialnych do wykonywania zadań publicznych.

Zmienia się także diagnoza podziału terytorialnego dokonywana przez instytucje państwowe. Rada Ministrów RP w 2000 r. uznała nowy podział administracyjny za poprawny. Jednocześnie wskazała za konieczne podjęcie pilnych inicjatyw zmierzających do łączenia się miast na prawach powiatu i powiatów mających siedzibę swych władz $\mathrm{w}$ tych miastach oraz przeprowadzenie niezbędnych korekt istniejącego podziału terytorialnego zmierzających do likwidowania lokalnych konfliktów, uwzględnienia więzi społecznych oraz lepszego wykorzystania środków publicznych. W 2001 r. Sejm i Senat zgodnie uznały nowy zasadniczy podział terytorialny państwa za spełniający założenia reformy administracji publicznej ${ }^{1}$.

W 2013 r. w Raporcie Ministerstwa Cyfryzacji i Administracji (Ocena sytuacji samorzq̨ów lokalnych, 2013, s. 42) zdiagnozowano, że „Szereg samorządów gminnych i powiatowych to jednostki małe i słabe finansowo. W perspektywie czasu mogą one nie być w stanie udźwignąć trudniejszych i droższych zadań publicznych starzejącego się kraju". Również w Raporcie o stanie samorząaności terytorialnej w Polsce (2013, s. 96) stwierdza się, że „Procesy demograficzne będą w coraz większym stopniu podważać finansowe podstawy funkcjonowania najmniejszych wspólnot samorządowych, zwiększać obciążenie budżetu państwa transferami do samorządów i osłabiać zdolność do świadczenia przez nie usług publicznych".

Nie relacjonując szczegółowo ww. ocen i stanowisk, w niniejszym artykule skoncentrowano się na charakterystyce ewolucji struktury terytorialno-administracyjnej kraju na poziomie gminnym w ostatnich 25 latach oraz przedstawieniu jej kluczowych problemów, istotnych także z punktu widzenia ewentualnych korekt w przyszłości. Podstawową tezą pracy jest stwierdzenie, że organizacja terytorialna administracji publicznej powinna zmieniać się w relacji do rozwoju procesów politycznych, gospodarczych, społecznych i co dla niej szczególnie istotne, także przestrzennych. Ich dynamika w ostatnich 25 latach skłania do refleksji nad dalszymi przekształceniami organizacji terytorialnej kraju. Charakterystykę organizacji terytorialnej kraju na poziomie gminnym poprzedzają roz-

${ }^{1}$ Uchwała Senatu Rzeczypospolitej Polskiej z dnia 11 stycznia 2001 r. w sprawie oceny nowego zasadniczego podzialu terytorialnego państwa. 
ważania na temat istoty, przesłanek oraz celów i metod zmian terytorialnych. Ich ukazanie pozwala na lepsze zrozumienie mechanizmów zmian w organizacji przestrzennej samorządu gminnego Polski w ostatnich 25 latach. Artykuł kończą wnioski i rekomendacje związane z kierunkami przekształceń lokalnych struktur administracyjnych.

\section{Przesłanki i cele zmian terytorialnych na poziomie lokalnym}

Zmiany struktury terytorialnej uważać należy za ostateczny środek usprawniania działań administracji publicznej. Niosą one bowiem ze sobą koszty zarówno materialne, finansowe i gospodarcze, jak i niematerialne, trudne do skwantyfikowania koszty społeczne (szerzej Elżanowski, 1982). Pomimo to okres po 1989 r. w Polsce obfitował w liczne zmiany podziału terytorialnego na szczeblu lokalnym, zarówno w odniesieniu do szczebli i liczebności jednostek terytorialnych, jak też ich granic oraz statusu administracyjnego. Ta duża częstotliwość wynikała z kilku przyczyn:

1) odziedziczony po okresie socjalistycznym podział terytorialny nie był do końca akceptowany. Odpowiadał on realiom zcentralizowanego i resortowo zarządzanego państwa (brak powiatów do 1998 r., małe województwa, odbiegające od współczesnego standardu regionu europejskiego);

2) niektóre gminy w swych rozmiarach przestrzennych nie odpowiadały zapisom ustawy o samorządzie gminnym z 8 marca 1990 r., (art. 4. ust. 1 pkt. 3), gdzie jednostki lokalne powinny być ,możliwie jednorodne ze względu na układ osadniczy i przestrzenny, uwzględniający więzi społeczne, gospodarcze i kulturowe oraz zapewniający zdolność wykonywania zadań publicznych";

3) rozwój trzeciego sektora gospodarki, wykształcenie się wielu nowych funkcji publicznych, zwłaszcza z zakresu administracji świadczącej, powodowały gwałtowny wzrost zadań administracji terytorialnej, także na poziomie lokalnym. Ciężar zadań władz lokalnych stawał się zbyt duży do udźwignięcia przez małe jednostki administracyjne;

4) rozwój samorządności przyniósł ze sobą rozwój świadomości lokalnej. Potrzeba samostanowienia leżała u źródeł zmian struktur gminnych. Jednocześnie jednak przywiązanie do tradycji i chęć niezależności są do dziś przyczyną niechęci do zmian granic gminnych.

Przesłanki podejmowanych $\mathrm{w}$ ostatnich latach zmian $\mathrm{w}$ organizacji terytorialnej gmin w różnych krajach europejskich, można podzielić je na następujące grupy (Kaczmarek, $2005)^{2}$ :

- przesłanki pragmatyczne, związane ze wzrostem efektywności zarządzania: efekt decentralizacji i reorganizacji sektora publicznego, chęć podniesienia wydajności działań administracji lokalnej w zaspokajaniu potrzeb mieszkańców;

${ }^{2}$ Dla porównania, Oitmaa i Roigas (2001), wymieniają cztery główne czynniki przekształceń struktur terytorialnych na poziomie lokalnym:

1) zmiany w systemie usług publicznych $i$ ich finansowaniu,

2) rozwój regionów funkcjonalnych nowego typu związany z procesami urbanizacji,

3) zmiany technologiczne $i$ informacyjne $w$ administracji,

3) zmiany społeczne: związane z identyfikacja społeczną i kulturowa tożsamością. 
- przesłanki finansowe: małe rozmiary przestrzenne gmin, ograniczona liczba zadań publicznych determinują szczupłość środków desygnowanych na szczebel lokalny oraz bardzo ograniczona decentralizacja fiskalna, co uniemożliwia faktyczną decentralizację władzy na poziom lokalny;

- przesłanki kadrowe: redystrybucja zadań na szczebel lokalny wymagała profesjonalizacji kadr administracyjnych, tworzenia wykwalifikowanego personelu. W większości małych gmin stanowiska we władzach i administracji nie miały charakteru etatowego, a poziom kwalifikacji pracowników był bardzo niski;

- przesłanki planistyczne: potrzeba wprowadzania nowych instrumentów planistycznych, strategii społeczno-gospodarczych i kompleksowych planów zagospodarowania przestrzennego, potrzeba redukcji „planowania zaściankowego” (niem. Inselplannung), charakterystycznego dla małych jednostek terytorialnych;

- przesłanki organizacyjno-technologiczne: rozwój środków komunikacji i informatyzacji w administracji, skrócenie czasu obiegu informacji, dokumentów itp. Stopniowe ograniczanie liczby kontaktów mieszkańca z urzędem, co z kolei powoduje zmniejszanie roli odległości między nimi;

- przesłanki komunikacyjne: rozwój masowej motoryzacji i publicznych środków transportu, co skraca drogę między obywatelem a władzą/urzędem;

- przesłanki ekonomiczno-przestrzenne: potrzeba dostosowania struktur terytorialnych do zmieniających się powiązań funkcjonalno-przestrzennych (np. w zakresie dojazdów do pracy, po usługi). Procesy urbanizacyjne, tercjaryzacja gospodarki wyzwalają nowe układy ciążeń społeczno-gospodarczych, które w skali lokalnej przyjmują postać mikroregionów społeczno-gospodarczych;

- przesłanki demograficzne: konieczność redukcji gmin karłowatych na terenach wiejskich, które wskutek procesów urbanizacyjnych (emigracje) i modernizacyjnych (spadek przyrostu naturalnego) uległy depopulacji;

- przesłanki społeczne: wynikające ze zwiększonej partycypacji społeczności lokalnych w procesie zarządzania i zwiększonego wpływu również na zmiany przebiegu granic administracyjnych ${ }^{3}$.

Z doświadczeń krajów europejskich wynika (m.in. Consolidation or fragmentation, 2002; Kaczmarek, 2005), że rozdrobniona organizacja terytorialna gmin rodzi wiele problemów natury strukturalno-ekonomicznej (wydajność i ekonomika skali działania jednostki administracyjnej), finansowej (brak samowystarczalności, własnych dochodów, możliwości finansowania inwestycji) i politycznej (konieczność kooperacji z sąsiednimi jednostkami). Biorąc pod uwagę powyższe przesłanki, w wyniku zmian terytorialno-administracyjnych oczekiwane są określone skutki polityczne, ekonomiczne i społeczne. Na przykład w procesie powiększania rozmiarów gmin w Niemczech na przełomie lat 60. i 70. zakładano osiagnięcie trzech zasadniczych celów (Hoffmann, Jacob, 1980):

1) likwidacja lub złagodzenie dysproporcji w zakresie rozwoju społeczno-gospodarczego między terenami zurbanizowanymi i wiejskimi;

2) wzmocnienie roli samorządu lokalnego;

3) wzrost efektywności działania administracji publicznej.

${ }^{3}$ W Polsce początkowo w drodze konsultacji społecznych a wraz z nowelizacją ustawy o samorzqdzie gminnym w 2011 r. także w drodze referendum lokalnego. 
Zadaniem zmian organizacji gminnej jest zatem nie tylko technokratyczna naprawa słabości ekonomicznej gmin, ale jednocześnie zaktywizowanie społeczności lokalnych i wykorzystanie endogenicznych czynników rozwoju poprzez wzrost samorządności gmin. Według Gustafssona (1992) zasadniczym celem reorganizacji gmin jest umocnienie demokracji lokalnej i zapewnienie mieszkańcom większego wpływu na rozwiązywanie lokalnych problemów w ich środowisku zamieszkania.

Zagadnienie wielkości jednostek administracyjnych należy do kluczowych problemów struktur terytorialnych i ich przekształceń. Jak zauważa Mouritzen (1989), problem ten jest żywo dyskutowany od czasów greckiego polis po współczesne debaty nad celowością i charakterem reform terytorialnych. We współczesnych badaniach nad wielkością jednostek terytorialnych, zwłaszcza lokalnych, kluczowym zagadnieniem stają się relacje, jakie zachodzą między rozmiarami gminy, z jednej strony, a skutecznością działania władz lokalnych w zakresie świadczenia usług publicznych i uczestnictwem społeczności lokalnej w życiu publicznym z drugiej strony. Dyskusje na ten temat toczą się od lat 50. XX w., kiedy to w kilku krajach Europy podjęto wysiłek przebudowy lokalnych struktur terytorialnych. Wraz z wprowadzeniem w życie pierwszych reform terytorialnych w powojennej Europie, w pełni ujawniły się sprzeczności między wzrostem efektywności działania jednostek lokalnych wraz z ich powiększaniem a osłabieniem uczestnictwa obywatelskiego w życiu publicznym. Ową dychotomię można sprowadzić do hasła Schumachera (1975) ,big is efficient - small is beautiful” czy alternatywy „,most efficient or most democratic" (Sharpe, 1995).

Teza o większych możliwościach $\mathrm{w}$ zakresie wykonywania zadań publicznych w większych terytorialnie, a przede wszystkim demograficznie jednostkach, wydaje się być niepodważalna. Tam, gdzie funkcjonują duże jednostki lokalne (kraje skandynawskie, Wielka Brytania, kraje Beneluksu), zakres ich kompetencji jest znaczny. Pojawiają się korzyści skali w wykonywaniu wielu usług, jednostki lokalne mają do dyspozycji większy zasób środków finansowych, czerpanych w dużym stopniu $\mathrm{z}$ własnych dochodów. Małe samorządy gminne, mimo najwyższych wydatków na mieszkańca, nie posiadają dużych zdolności rozwojowych i nie są w stanie skutecznie wpływać na podniesienie jakości życia swoich mieszkańców. Nie chodzi tu tylko o potencjał finansowy. Jednostki takie mają ograniczone eksperckie zasoby kadrowe, przez co niższy jest ich ogólny potencjał instytucjonalny. Wpływa to negatywnie na warunki bieżącego zarządzania i rozwoju tych wspólnot.

Większa skala jednostek sprzyja realizacji strategii rozwoju lokalnego, ogranicza także niekorzystny efekt spillovers, czyli nie pokrywania się miejsc korzystania z usług z miejscami zamieszkania i płaceniem podatków w gminie (Keating, 1995; Swianiewicz, 2000). Jak zauważa Tiebout (1956), mniejsze jednostki mogą być zamieszkałe przez bardziej jednorodne społeczności, a zatem zaspokajanie ich potrzeb jest łatwiejsze. Mniejsza skala, według Stokera (1997), czyni samorządy podatnymi na zmiany. Transparentność decyzji samorządowych ułatwia presję, jaką mieszkańcy mogą wywierać na władze, w sytuacji, gdy nie są należycie zaspokajane ich potrzeby. Silną linię obrony małych jednostek lokalnych w Anglii przedstawili Jones i Stewart (1983, s. 6) uznając, że tylko władze takich jednostek są podatne na wpływ wywierany przez mieszkańców, ponieważ „radni i urzędnicy żyją blisko decyzji, które podejmują, blisko ludzi, na których życie oddziałują i blisko obszaru, który kształtują”. „Samorząd będąc mniej odległy 
sprawia, że władza może postępować bardziej spójnie, umożliwia jasny i zrównoważony wybór promowania wartości wyznawanych przez społeczność lokalną" (Jones, Stewart, 1983, s. 7).

W opozycji do „lokalizmu” ukształtował się nurt poglądów związanych z orientacją rynkową usług administracyjnych, według której przecenia się rolę demokracji lokalnej i jej wpływu, tak na sprawne działanie polityki lokalnej, jaki i poziom świadczenia usług komunalnych. Teoretycy koncepcji wyboru publicznego (public choice) uznaja, że mechanizmy demokracji bezpośredniej są słabym wskaźnikiem preferencji i potrzeb mieszkańców (Niskanen, 1973; Pirie, 1983; Boddy, 1987). Dowodem na to jest spadająca frekwencja wyborcza na poziomie lokalnym, podleganie samorządów wpływom grup interesu i partii politycznych. Krytyka lokalizmu obejmuje więc nie tylko niską efektywność małych jednostek administracyjnych, ale także ich słabości polityczne związane z zagrożeniami lokalnej demokracji. Z kolei zwolennicy lokalizmu uważaja, że mimo oczywistych mankamentów, funkcjonowanie niewielkich jednostek lokalnych ma rację bytu poprzez reformy organizacyjne i zmiany stylu zarządzania, polegające na: „otwartości, zdolności uczenia się i innowacyjności samorządów” (Stoker, 1997, s. 21).

Podsumowując dyskusję nad strukturą jednostek lokalnych należy zauważyć, że liczba argumentów za ich małą bądź dużą skalą jest znaczna i stale się zmienia. Zwolennicy lokalizmu wierzą w samoorganizację małych samorządów, ich innowacyjność i zdolność do przezwyciężania mankamentów oraz deficytów zarządzania w małej skali przestrzennej. Z kolei zwolennicy powiększania zakresu przestrzennego działania jednostek lokalnych argumentują to względami ekonomicznymi (ekonomiki skali), jak też zmianami kulturowymi, które przejawiają się stopniowym zanikiem lokalizmu, przynajmniej w wariancie polityczno-administracyjnym. Każda dyskusja i propozycje zmian struktury terytorialnej muszą uwzględniać różne czynniki związane z prakseologią zarządzania i ekonomiką skali, jak też uwarunkowania geograficzne, historyczne i społeczne.

\section{Formy i tryb lokalnych zmian terytorialnych}

Zmiany terytorialnej organizacji jednostek lokalnych sprowadzają się do powiększania lub pomniejszania ich granic oraz modyfikacji liczby gmin (poprzez ich redukcję lub zwiększanie). Zmiany granic jednostek lokalnych mogą przybierać różnorodne formy, zależne zarówno od uwarunkowań geograficznych, społecznych i ekonomicznych, jak i przyjętych rozwiązań prawnych. Zasadniczo zmiany te następują na drodze:

1) secesji, czyli oddzielenia, odłączenia się pewnej części gminy i utworzenia nowej jednostki terytorialnej;

2) komasacji (amalgamacji, fuzji, agregacji) - połączenia, scalania gmin, czyli tworzenia nowej, większej jednostki, najczęściej z 2. lub więcej sąsiednich gmin;

3) aneksji, czyli włączenia przez zwykle większą jednostkę gminną całości lub czesści terytorium mniejszej jednostki, praktykowana najczęściej na terenach podmiejskich, gdzie np. rozwijające się terytorialnie miasto inkorporuje tereny podmiejskie;

4) fragmentacji, czyli likwidacji gminy przez podział jej terytorium między sąsiadujące z nią jednostki; 
5) parcelacji, czyli podziału gminy na dwie lub więcej jednostek;

6) kreacji, tworzenia nowej gminy na bazie terytoriów utraconych przez sąsiednie jednostki (ryc. 1).

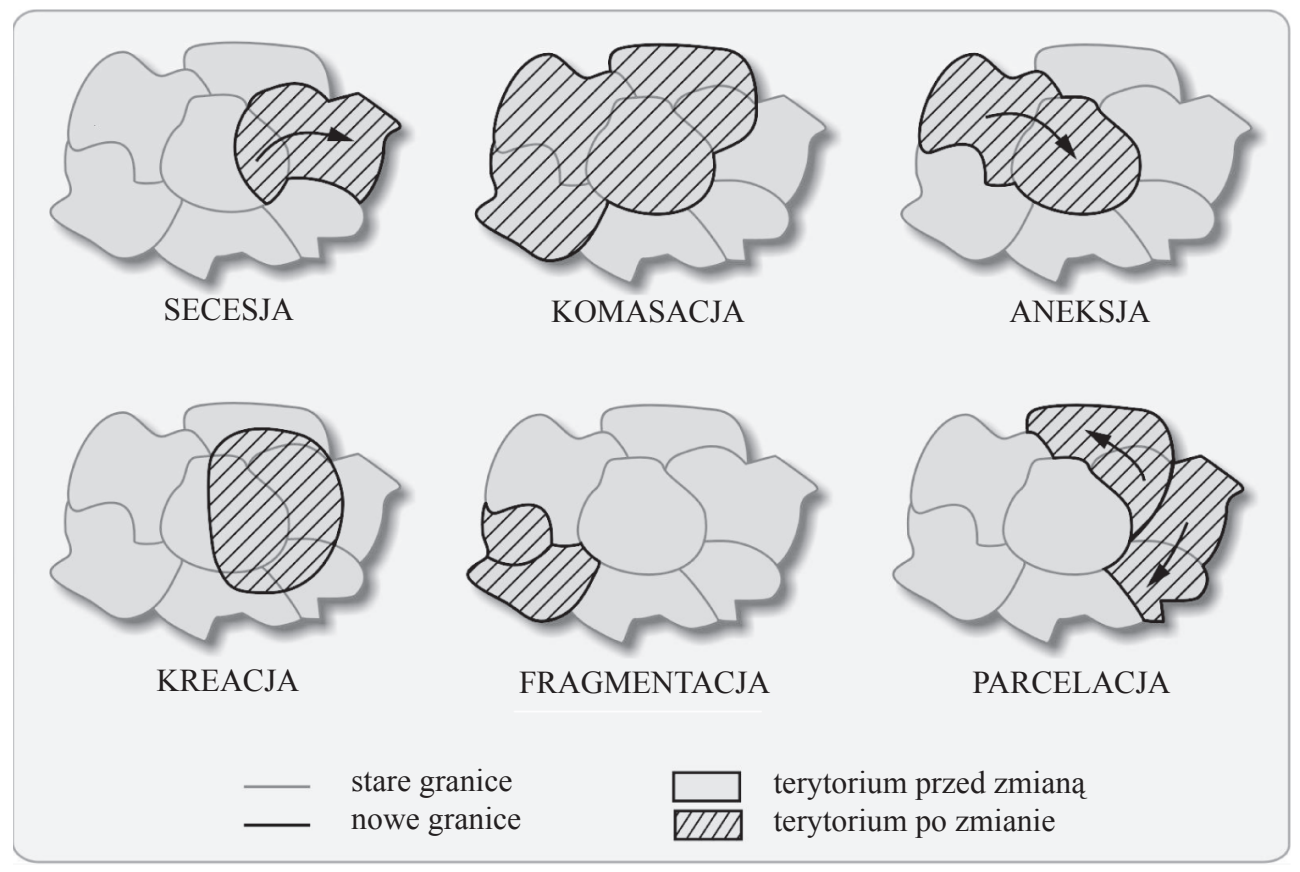

Ryc. 1. Formy zmian granic administracyjnych jednostek lokalnych.

Źródło: Kaczmarek, 2005.

Dominująca w ostatnich kilkudziesięciu latach w krajach europejskich jest tendencja do powiększania rozmiarów jednostek lokalnych. W tym względzie stosowane jest najczęściej połączenie dotychczas samodzielnych gmin w jedną dużą gminę zbiorczą (niem. Einheitsgemeinde, szwedz. kommunblock).

Reformy gminne moga mieć charakter zarówno dobrowolny, jak i przymusowy. W pierwszym przypadku następuje to na drodze porozumienia władz gminy, np. poprzez uchwały rad gmin lub w rezultacie wyrażenia woli społeczności lokalnej poprzez np. referendum. Nie obligatoryjne zmiany granic administracyjnych wymagają również form prawnych, takich jak porozumienie między objętymi zmianami granic gminami. Porozumienie to reguluje zwykle najważniejsze z punktu widzenia interesów społeczności lokalnych sprawy, takie jak: zakres zmian terytorialnych, regulacje prawa miejscowego, uregulowania dotyczące organów władzy gminy i jej administracji, przejęcie zobowiązań, organizacja wyborów, ustalenie nazwy jednostki administracyjnej itp. Przykładem dobrowolnych fuzji gmin są rozwiązania na Łotwie, Słowacji, w Czechach, we Francji czy w Niemczech Wschodnich (w początkowym etapie reformy).

W przypadku reform obligatoryjnych, zmiany granic administracyjnych moga następować z tytułu nakazu o randze ustawy państwowej np. w Holandii, Belgii, 
Szwecji, na Litwie lub aktu prawnego leżącego w kompetencji rządu - ministerstwa lub jednostek niższego rzędu np. w Niemczech - regulacji kraju związkowego, w Finlandii - decyzji władz prowincjonalnych. W historii reform gminnych daje się zauważyć wyraźny konflikt między nakazowymi a dobrowolnymi zmianami granic gmin. W prawodawstwie europejskim (Europejska Karta Samorządu Lokalnego), jak i krajowym unika się klauzul o nienaruszalności granic gminnych, dopuszczając tym samym wpływ (ingerencję) państwa na zmiany tychże granic. Na ogół silne gwarancje - konstytucyjne - dotyczą tylko instytucji samorządu terytorialnego, a nie przestrzennych ram jego działania. „Odgórne” zmiany granic terytorialnych są więc dopuszczalne, zwłaszcza jeśli przemawiają za tym ważne interesy państwowe czy też względy ogólnospołeczne 4 . Hoffmann i Jacob (1980), zaliczają do nich następujące sytuacje:

- wzmocnienie potencjału ekonomicznego gmin;

- ujednolicenie warunków życia i jakości środowiska;

- niwelowanie różnic między terenami zurbanizowanymi a wiejskimi;

- podnoszenie efektywności działań administracji;

- ułatwienie wykonywania i podejmowanie nowych zadań publicznych.

W polskiej procedurze prawnej, w myśl zapisów art. 4 ust. 1 ustawy o samorządzie gminnym (dalej UOSG), kompetencje w zakresie zmian terytorialnych jednostek samorządu terytorialnego zostały nadane Radzie Ministrów. Ustawodawca przyznał wyłączne kompetencje Radzie Ministrów w zakresie tworzenia, łączenia, dzielenia, a nawet i znoszenia gminy. Nadto, to wyłącznie Rada Ministrów wyposażona została w kompetencję do nadawania gminie lub miejscowości statusu miasta i ustalania jego granic. W przypadku ustalania lub zmiany granic gmin, Rada Ministrów musi uwzględnić następujące przesłanki (art. 4 ust. 3 UOSG):

- wymóg maksymalnej jednorodności/spójności terytorialnej poprzez analizę układu osadniczego i przestrzennego w zakresie występowania więzi społecznych, gospodarczych oraz kulturowych;

- wymóg takiego kształtowania granic jednostek podziału terytorialnego, które zapewni zdolność wykonywania zadań publicznych.

Sobota, Jawecki, Tokarczyk-Dorociak (2012), analizując dotychczasowe przypadki nadawania zmian granic gmin zwracają uwagę, że zasadniczo akcentowane są w szczególności:

- aspekty funkcjonalno-przestrzenne (powiązania poprzez infrastrukturę techniczną i drogową; charakterystyka procesów przestrzennych w analizowanym rejonie, w szczególności proces rozwoju zabudowy; potrzeby rozwojowe np. miasta - tereny pod inwestycje); oraz

- aspekty społeczne (wyniki konsultacji społecznych, opinie właściwych rad oraz wojewody).

W 2011 r. w ramach nowelizacji UOSG z dn. 26.05. dodany został m.in. art. 4c stanowiący, iż w sprawie utworzenia, połączenia, podziału i zniesienia gminy oraz ustalenia

${ }^{4} \mathrm{~W}$ ustawodawstwie niemieckim względy publiczne określa się jako „Gründe des öffentlichen Wohls". W literaturze często podkreśla się nieokreślony i względny charakter tego pojęcia, co komplikuje sytuację prawną reform komunalnych i rodzi spory na linii organy reformatorskie państwa, a poddane procesowi reformy jednostki administracyjne. 
granic gminy może być przeprowadzone referendum lokalne z inicjatywy mieszkańców (z inicjatywą przeprowadzenia takiego referendum może wystąpić grupa co najmniej 15 osób, którym przysługuje prawo wybierania do rady gminy). Pozytywny wynik takiego referendum jest dla rady gminy wiążący, w tym sensie, że jest ona zobowiązana wystąpić do Rady Ministrów z wnioskiem o wydanie rozporządzenia, o którym mowa w art. 4 ust. 1 pkt 1 UOSG, jednakże ostateczna decyzja w sprawie zmiany granic pozostaje nadal w wyłącznej kompetencji Rady Ministrów. Takie ukształtowanie regulacji prawnych wskazuje na zasadę trwałości granic jednostek podziału terytorialnego, która ma znaczenie w procesie kształtowania się prawidłowych więzi społecznych i gospodarczych niezbędnych dla właściwego funkcjonowania wspólnoty samorządowej oraz na konstytucyjną ochronę przedmiotowej wartości (Chmielnicki, 2010).

\section{Zmiany liczby gmin w latach 1990-2016}

Struktura terytorialna na poziomie gminnym w obecnym kształcie to efekt reformy terytorialnej z 1973 r. i konsekwencji reformy samorządowej z 1990 r. Konsolidacja gmin w 1973 r. (po nieudanej „reformie gromadzkiej” 1954-1972) uczyniła z nich mikroregiony społeczno-gospodarcze, z centralnym ośrodkiem wiejskim lub miejskim i lokalnym układem osadniczym, złożonym średnio z kilkunastu wsi. Ukształtowany wówczas podział gminny z zasadniczej formie przetrwał do dziś.

Z punktu widzenia przekształceń terytorialnych struktur lokalnych po okresie transformacji ustrojowej, najistotniejsze znaczenie miał wzrost liczby gmin. Był on efektem procesu fragmentacji gmin w wyniku demokratyzacji życia publicznego po 1990 r. Proces ten wydawał się nieunikniony ${ }^{5}$. Restytucja samorządu terytorialnego, wolne wybory do władz lokalnych, odrodzenie patriotyzmów lokalnych, początkowy brak państwowej wizji co do przekształceń administracji terytorialnej na wyższych szczeblach, stanowiły główne uwarunkowania znacznej reorganizacji terytorialnej struktur lokalnych. Brak poważnych ograniczeń ustawowych w zakresie parcelacji gmin w pierwszej połowie lat 90. przyniósł żywiołowy wzrost liczby gmin (tab. 1). Ich liczba w latach 1990-2000 wzrosła z 2122 do 2489 tj. o 17\%. Wśród przyczyn procesu rozdrabniania gmin należy zwrócić uwagę na następujące:

1) brak zapisów ustawowych, co do kryteriów podziału gmin sprawił, że ich podział przebiegał w sposób żywiołowy i niekontrolowany;

2) powstawanie nowych jednostek lokalnych, jako przejaw oddolnych ruchów społecznych i demokratyzacji życia w nowych warunkach ustrojowych;

3) restytucji gmin, które zniknęły z mapy administracyjnej w wyniku reform komasacyjnych;

4) podziałów jednostek lokalnych na tle politycznym, wynikającym z różnic w pogląach na temat rozwoju gminy w radach gminnych i odpowiadających im terytoriach.

5 Jak zauważa P. Swianiewicz (2002) ze względu na autorytarny charakter zmian terytorialnych w krajach realnego socjalizmu, nie powinno być zaskoczeniem, że zaraz po roku $1990 \mathrm{w}$ niektórych z nich pojawiła się silna presja oddolna w kierunku uzyskania samodzielności, przez miejscowości przymusowo przyłączane do większych jednostek. 
Liczba i wielkość gmin w Polsce w latach 1946-2016.

\begin{tabular}{|c|c|c|c||}
\hline Lata & Liczba gmin & $\begin{array}{c}\text { Srednia powierzchnia } \\
\text { gminy } \mathbf{( w ~}_{\mathbf{~ k m}} \mathbf{)}\end{array}$ & $\begin{array}{c}\text { Srednia liczba ludności } \\
\mathbf{( w ~ t y s . )}\end{array}$ \\
\hline 1946 & 3006 & 104 & 7,8 \\
\hline 1955 & 8789 (gromady) & 36 & 3,1 \\
\hline 1973 & 2365 & 132 & 13,8 \\
\hline 1980 & 2070 & 151 & 17,2 \\
\hline 1989 & 2121 & 147 & 18,2 \\
\hline 1994 & 2465 & 127 & 15,7 \\
\hline 2002 & 2478 & 125 & 15,6 \\
\hline 2014 & 2479 & 125 & 15,5 \\
\hline 2016 & 2478 & 125 & 15,5 \\
\hline
\end{tabular}

Źródło: Zestawienie własne na podstawie danych GUS.

Parcelacja gmin w szczególności dotyczyła terenów zurbanizowanych i objęła podziały sztucznie łączonych przed 1989 r. miast i gmin (tzw. miasta zlepieńce - Szmytke, 2009). Stąd odtworzenie samorządnych gmin dotyczyło głównie gmin podmiejskich, wcześniej inkorporowanych w granice miast. Szczególnie miało to miejsce na Górnym Śląsku, gdzie w latach 70. i 80. XX w. w granice miast włączano przyległe gminy wiejskie. Jarczewski (2002) zwraca uwagę, że większość inkorporacji już wtedy budziło niezadowolenie społeczne ${ }^{6}$. Likwidowane gminy leżały z reguły z dala od centrów większych miast, oddzielone były od nich pasami zieleni, nieużytków bądź terenów przemysłowych. Słabe przez to były powiązania infrastrukturalne i komunikacyjne między łączonymi jednostkami. Na Górnym Śląsku niemal każda gmina (również wiejska) była silnie uprzemysłowiona. W tym czasie słabe więzi funkcjonalne (np. dojazdy do pracy) nie stanowiły więc istotnego argumentu dla zmian terytorialno-administracyjnych. W efekcie, jak zauważa Jarczewski (2002), likwidowane gminy nie były klasycznymi sypialniami dużych miast, ale autonomicznymi jednostkami ekonomicznymi i osadniczymi, z własnymi zakładami pracy i z wykształconymi centrami usługowymi.

W zlikwidowanych gminach suburbialnych uśpione przez lata aspiracje administracyjne obudzily się po 1989 r. wraz z odrodzeniem samorządności lokalnej. W wielu z nich powstały społeczne akcje na rzecz restytucji gminy, głównie inspirowane i prowadzone przez lokalnych liderów opinii publicznej. Argumenty za odłączeniem zyskiwały poparcie mieszkańców gmin. Akcentowano niedorozwój gmin przez lata braku ich samodzielności, małą reprezentację polityczną we władzach dużego miasta, słabe więzi infrastrukturalne i funkcjonalne z miastem (Kaczmarek, 2005). Ważnym argumentem za restytucją gmin była ich znaczna niezależność ekonomiczna. Na ich terenie, jak już

${ }^{6}$ Inkorporacje gmin podmiejskich do miast, choć budziły niezadowoleni społeczne, w połowie lat 70. XX w. nie stały się przedmiotem protestów społecznych, tak jak miało to miejsce w niektórych krajach Europy Zachodniej (zob. Kaczmarek, 2005). Z jednej strony społeczności lokalne były zbyt ubezwłasnowolnione, a ich reprezentanci - lokalne struktury władzy - zbyt upolitycznione. $Z$ drugiej strony, charakterystyczna dla lat 70. propaganda sukcesu, kreowała w świadomości społecznej obraz szybkiego rozwoju społeczno-gospodarczego. W przyłączeniu do dużego miasta niektórzy mieszkańcy widzieli szansę (jak się okazało często iluzoryczną) na poprawę własnych warunków życia i czerpanie korzyści z atrybutów ,wielkomiejskości” nowej jednostki administracyjnej. 
wspominano, funkcjonowały często duże zakłady pracy, generujące przychody do budżetu gminy. Poparcie idei usamodzielnienia się gmin sięgało 80-90\% mieszkańców, co świadczyło o wciąż dużej identyfikacji terytorialnej z utraconą jednostką administracyjną. W obliczu silnych argumentów ekonomicznych i społecznych (popartych wynikami referendum, petycjami społecznymi do władz wojewódzkich i centralnych), w przypadku najbardziej zdeterminowanych jednostek, doszło za zgodą Prezesa Rady Ministrów RP do ich wydzielenia ze struktur miejskich i ukonstytuowania się nowych gmin.

Powstawanie nowych gmin zostało ograniczone po 1998 r., z chwilą restytucji drugiego szczebla samorządu lokalnego - powiatów. Rada Ministrów wprowadziła wówczas bardziej zaostrzone kryteria tworzenia gmin, uwzględniające czynniki demograficzne, infrastrukturalne i ekonomiczne. Bardziej rygorystycznie interpretowano obowiązujące zapisy ustawy o samorządzie gminnym, mówiące (art. 4 ust. 3 UOSG) o maksymalnej jednorodności/spójności terytorialnej oraz zdolność wykonywania zadań publicznych. Wnioski o reaktywowanie gmin spotykały się coraz częściej z negatywną oceną organu opiniującego ${ }^{7}$. Ministerstwo Spraw Wewnętrznych i Administracji stało na stanowisku, że dążenie do podziału gmin jest tendencją przeciwną do kierunku polityki państwa, polegającej na utrzymaniu jednostek dużych i silnych, gdyż takie jednostki posiadają większe możliwości budżetowe, większe możliwości absorpcji środków unijnych, a także efektywniej gospodarują środkami publicznymi. W latach 2002-2014 powstała w Polsce tylko jedna gmina - Jaśliska w województwie podkarpackim ${ }^{8}$.

W obecnie obowiązującej UOSG art. 4d mówi, że Rada Ministrów nie wyda zgody na utworzenie gmin, których:

1) dochody podatkowe na mieszkańca gminy w zmienionych granicach lub gminy utworzonej byłyby niższe od najniższych dochodów podatkowych na mieszkańca ustalonych dla poszczególnych gmin, zgodnie z ustawą z dnia 13 listopada 2003 r. o dochodach jednostek samorządu terytorialnego;

2) gmina w zmienionych granicach lub gmina utworzona byłaby mniejsza od najmniejszej pod względem liczby mieszkańców gminy w Polsce.

Wyżej wskazane dwa zapisy stanowią istotną barierę dla powstawania gmin, jak na polskie warunki karłowatych i niewydolnych ekonomicznie. Szczególnie w obliczu wprowadzenia w ramach nowelizacji UOSG z 2011 r. przepisów, które umożliwiają mieszkańcom występowanie z inicjatywą utworzenia, połączenia, podziału i zniesienia gminy oraz ustalenia granic jednostki. Jest ona realizowana $\mathrm{w}$ formie referendum lo-

${ }^{7} \mathrm{~W}$ ostatnich latach z różnych powodów chęć usamodzielnienia się i utworzenia gminy zgłaszały m.in. Szczawa (wydzielenie z gminy Kamienica), Grabówka (z gminy Supraśl), Komorów (z gminy Michałowice), Chełmsko Śląskie (z gmin Lubawka i Kamienna Góra), Kamyk (z gminy Kłobuck), Jankowice (z gminy Świerklany), Łagiewniki (z miasta Łodzi).

${ }^{8}$ Gmina Jaśliska czyniła starania o reaktywacje od 2006 r. i dopiero po trzeciej próbie, zgodnie z rozporządzeniem Rady Ministrów z dnia 28 lipca 2009 r. została utworzona 1 stycznia 2010 r. MSWiA rozpatrując wniosek gminy, pominęło uwarunkowania demograficzne i ekonomiczne (gmina Jaśliska liczy zaledwie 2077 mieszkańców i ma niewielkie możliwości dochodowe). Pozytywną decyzję uzasadniło natomiast argumentami społecznymi i geograficznymi, takimi jak: wola mieszkańców lokalnej społeczności, lokalne więzi społeczne, historyczne i gospodarcze, jednorodność terytorium pod względem osadniczym oraz zwartość zamieszkałego terenu i jego znaczne oddalenie od siedziby dotychczasowej gminy Dukla, co stanowiło znaczne utrudnienie - zwłaszcza w okresie zimowym - ze względu na trudne warunki terenowe (położenie w obszarze górskim). 
kalnego. Do tej pory udział mieszkańców w podejmowaniu decyzji o granicach gminy sprowadzał się do obowiązkowych konsultacji społecznych organizowanych przez jednostkę samorządową. Wynik konsultacji jednak nie był wiążący dla władz. Po wejściu w życie znowelizowanych przepisów, rozstrzygające referendum lokalne jest podstawą do wydania przez Radę Ministrów rozporządzenia w sprawie utworzenia, połączenia, podziału i zniesienia gminy oraz ustalenia jej granic ${ }^{9}$.

\section{Zmiany statusu administracyjnego oraz granic gmin}

W Polsce, według stanu na 1 stycznia 2016 r., funkcjonowało 2478 gmin, z czego 1559 były to gminy wiejskie, 616 gmin miejsko-wiejskie oraz 303 gminy miejskie (w tym 66 będących jednocześnie miastami na prawach powiatu). Podkreślić należy, iż w UOSG nie dokonany został podział pojęciowy określeń: gmina miejska, gmina wiejska oraz gmina miejsko-wiejska, co jest konsekwencją jednolitości rozwiązań ustrojowych w zakresie statusu prawnego jednostki samorządu gminnego.

Z punktu widzenia racjonalizacji zarządzania publicznego za najbardziej dyskusyjny uznać należy fakt istnienia 158 gmin wiejskich, których siedziba mieści się w sąsiedniej gminie miejskiej (to około $10 \%$ ogółu gmin wiejskich). Urząd takiej gminy bardzo często siedzibę ma nie tylko w mieście, gdzie równolegle działa urząd miasta na czele $\mathrm{z}$ burmistrzem lub prezydentem, ale nawet $\mathrm{w}$ tym samym budynku. Wśród gmin mających siedzibę w mieście, gdzie równocześnie funkcjonuje gmina miejska, są zarówno niewielkie gminy, takie jak: Obrzycko (woj. wielkopolskie), które jako miasto (M) liczy 2,2 tys. a gmina wiejska (W) 4,4 tys. mieszkańców, Stoczek Łukowski (woj. lubelskie), M: 2,7 tys. i W: 5,1 tys. mieszkańców oraz Kowal (kujawsko-pomorskie) odpowiednio M: 3,5 tys. i W: 4,0 tys. mieszkańców, jak i gminy zdecydowanie większe, np. Ełk (M: 57,5 tys., W: 10,6 tys.), Włocławek (M: 117,3, W: 6,5) oraz Tarnów (M: 114,2, tys., W: 24,1 tys.).

Istnienie gminy wiejskiej, szczególnie małej, wokół odrębnej jednostki miejskiej jest o tyle nieracjonalne, że większość usług skoncentrowanych jest i świadczonych w mieście, które stanowi ośrodek centralny także dla zaplecza wiejskiego. Gmina wiejska ma więc bardziej uzasadnienie polityczne niż ekonomiczne. Jak zauważa Walczak (2012), funkcjonowanie jednocześnie obu tych podmiotów skutkuje koniecznością utrzymywania podwójnej administracji samorządowej oraz m.in. ograniczoną koordynacją działań, strategii i planów rozwoju przestrzennego. W przypadku większych miast oznacza to także problemy gospodarcze w związku z przeniesieniem inwestycji (mieszkaniowych i produkcyjnych) na obszary wiejskie. Jakiekolwiek zmiany czy nawet sama dyskusja są często traktowane przez gminy wiejskie jako zamach na samorządność. Mieszkańcy tych podnoszą także kwestie ewentualnego podniesienia podatku rolnego lub podatku od nieruchomości.

Wyjściem z tej sytuacji są zasadniczo trzy możliwe działania: 1) połączenie gminy miejskiej i wiejskiej w gminę miejsko-wiejska;

9 W 2015 r. w uzasadnieniu niepowoływania gmin Grabówka oraz Szczawa Rada Ministrów powołała się na negatywne wyniki gminnych referendów, które zostały przeprowadzone w ww. gminach w ramach konsultacji społecznych. 
2) włączenie gminy wiejskiej w granice miasta i utworzenie jednej dużej gminy miejskiej;

3) włączenie części gminy wiejskiej do miasta, z zachowaniem obu jednostek samorządowych w zmienionych granicach terytorialnych.

Przykładem utworzenia wspólnej gminy miejsko-wiejskiej po 1989 r. były zmiany dokonane w gminach Żychlin (połączone miasto Żychlin i gmina Dobrzelin), a także połączenia gminy i miasta: Andrychów, Chełmek, Kalwaria Zebrzydowska, Kęty, Maków Podhalański, Pasłęk, Skoczów, Strumień, Wadowice, Wilamowice i Zator.

Kwestia łączenia gmin i ich konsolidowania w organizmy silniejsze i bardziej wydolne, choć trudna społecznie, ma wsparcie ekonomiczne ze strony państwa. Dobrowolne fuzje gmin mają zagwarantowane zwiększenie udziału we wpływach podatkowych z PIT (podwyższony wskaźnik udziału o 5 punktów procentowych przez okres pięciu kolejnych lat). O możliwości uzyskania takiej premii mówi art. 41. pkt 1. ustawy o dochodach jednostek samorządu terytorialnego z 2003 r., według którego: „Dla gminy powstałej w wyniku połączenia dwóch lub więcej gmin, w drodze zgodnych uchwał, wskaźnik udziału we wpływach z podatku dochodowego od osób fizycznych, określony w art. 4 ust. 2, w okresie 5 lat, począwszy od dnia 1 stycznia roku następującego po roku, w którym podjęto decyzję o połączeniu, jest zwiększony o pięć punktów".

Mechanizm finansowy, dedykowany od 2003 r. szczególnie słabym ekonomiczne gminom, jak do tej pory nie zadziałał. W ostatnich latach w Polsce doszło tylko do jednego połączenia samorządów (na mocy rozporządzenia Rady Ministrów z 29 lipca 2014 r.): miasta na prawach powiatu Zielona Góra $\mathrm{z}$ gminą Zielona Góra w jednostkę samorządu terytorialnego miasta na prawach powiatu Zielona Góra. Tym samym miasto Zielona Góra powiększyło swój obszar z $58,34 \mathrm{~km}^{2}$ do $278,79 \mathrm{~km}^{2}$, a liczbę ludności o około 20 tys. W skład miasta weszły wszystkie sołectwa dawnej gminy wiejskiej i utworzyły dzielnicę Nowe Miasto, która od 2 stycznia 2015 r. funkcjonuje jako część administracyjna miasta Zielona Góra. Dzięki fuzji samorządów Zielona Góra otrzyma tzw. „ministerialny bonus” - przez pierwsze pięć lat będą to zwiększone udziały w podatkach PIT i CIT (łącznie kwota około $80 \mathrm{mln}$ zł). W ślad za Zieloną Górą również inne samorządy rozważały fuzję miasta i gminy wiejskiej, m.in. Lubin, Gniezno czy Elbląg.

Z inicjatywą włączenia gmin podmiejskich w granice miasta wystąił w 2015 r., na początku swojej kadencji prezydent Poznania. W myśl tej koncepcji miasto miałoby inkorporować 3 gminy podmiejskie: miasto Luboń oraz dwie gminy wiejskie: Suchy Las i Komorniki. Główną przesłanką fuzji miałaby być premia ministerialna, którą w okresie 5 lat szacowano na okolo $400 \mathrm{mln}$ zł. Ten niezbyt fortunny pomysł arbitralnego włączania w granice Poznania gmin: dużych (Luboń - 30,3 tys. mieszkańców) i silnych ekonomicznie (gmina Suchy Las ma dochody budżetowe na 1 mieszkańca większe niż miasto Poznań), nie spotkała się z dobrym przyjęciem przez władze i mieszkańców gmin podpoznańskich. Podważyła też wzajemne zaufanie samorządów, budowane od kilku lat w ramach struktur - najpierw porozumienia aglomeracja poznańska a potem Stowarzyszenia Metropolia Poznań. Rządowy bonus finansowy dla łączących się gmin pomyślany jest głównie jako wsparcie dla fuzji słabych ekonomicznie gmin, aby zracjonalizować zarządzanie lokalne, czego gwarancji w przypadku powiększania granic Poznania tak naprawdę nie można wykazać. 
Warto zauważyć, że oprócz łączenia gmin miejskich i wiejskich w ostatnich latach miały miejsce także przypadki odwrotne, to znaczy wydzielania z miast obszarów wiejskich i tworzenia z gmin miejskich gmin o statusie miejsko-wiejskim. Przykładem są tu gminy Szczawnica (2008), Czarna Woda (2014) i Władysławowo (2015). W przypadku gminy Władysławowo 1 stycznia 2015 r. wyłączono poza administrację miasta obszary siedmiu miejscowości (m.in. Chałupy, Rozewie, Jastrzębia Góra), nadając im status wsi. Zmiana statusu gminy podyktowana była wieloma względami. Każda z miejscowości wskazanych do wyłączenia z miasta Władysławowo posiada dość jednorodny układ osadniczy i przestrzenny, wspólne ujęcie wody oraz oczyszczalnię ścieków. Zmiana statusu gminy na miejsko-wiejską przynosi także gminie i mieszkańcom terenów wymierne korzyści. Umożliwia m.in. skorzystanie ze środków Unii Europejskiej przeznaczonych dla obszarów wiejskich, a także co w obszarze nadmorskim jest szczególnie ważne: tworzenie gospodarstw agroturystycznych (wynajem do pięciu pokoi w gospodarstwach rolnych bez konieczności rejestracji działalności gospodarczej) i dostęp do kredytów z tym związanych.

Ostatnim przypadkiem zmian granic gminnych są inkorporacje części terenów podmiejskich w granice miasta. Tu główną przesłanką jest chęć pozyskania nowych terenów inwestycyjnych, szczególnie pod rozwijane w wyniku suburbanizacji budownictwo mieszkaniowe. Opór gmin podmiejskich jest tu znaczny. Przykładem znacznego powiększania terytorium miasta kosztem gmin ościennych jest Rzeszów. W latach 2005-2010 władzom miasta udało się powiększyć granice miasta niemal trzykrotnie z $53,69 \mathrm{~km}^{2}$ do $116,37 \mathrm{~km}^{2}$, o tereny należące do pięciu ościennych gmin Świlcza, Boguchwała, Krasne, Tyczyn i Głogów Małopolski.

Przedstawione powyżej przykłady świadczą o znacznej dynamice organizacji terytorialnej gmin w Polsce. W ostatnich 25 latach zmienia się ich liczba, granice oraz status administracyjny. Świadczy to z jednej strony o możliwościach ustawowych dokonywania zmian oraz oddolnych inicjatywach reorganizacji struktur terytorialnych, pojawiających się stosownie do zmieniających się warunków lokalnych.

\section{Podsumowanie}

Zarówno racje ekonomiczne, jak i wymogi sprawnego zarządzania państwem skłaniają do urzędowego łączenia małych i słabych ekonomicznie gmin. Jak zauważają autorzy raportu Ocena sytuacji samorządów lokalnych (2013, s. 25), „Znaczące rozdrobnienie samorządów, które charakteryzuje niemałą grupę gmin, generuje wysokie koszty finansowe ich funkcjonowania". Zwiększa też problem koordynacji w realizacji szeregu zadań publicznych. W wyżej wymienionej ekspertyzie wymienia się potencjalne korzyści, jakie mogłoby przynieść łączenie samorządów, uporządkowane według następujących grup:

- zwiększenie jakości, dostępności i wydajności świadczonych usług, zdolność większych samorządów do dostarczania usług o wyższym standardzie;

- lepsze świadczenie wyspecjalizowanych usług ze względu na posiadane zasoby; urealnienie granic administracyjnych w stosunku do zasięgu niektórych usług publicznych (np. lokalnego transportu publicznego, szkół); 
- możliwość zatrudnienia bardziej wyspecjalizowanych pracowników, większe samorządy, jako atut państwa wobec wyzwań globalizacji: mobilności podatników, mieszkańców i bardziej złożonej rzeczywistości; redukcja problemu koordynacji zadań poprzez ograniczenie liczby samorządów;

- poprawa efektywności realizacji zadań (efekt skali) w szczególności tych, których realizacja wymaga znacznych nakładów inwestycyjnych (np. oczyszczalnie ścieków), oszczędności finansowe: ograniczenie liczby stanowisk kierowniczych, ograniczenie wydatków administracyjnych; zmniejszenie zróżnicowania dochodów JST na danym szczeblu; bardziej sprawiedliwe rozłożenie kosztów usług publicznych poprzez urealnienie granic samorząáów.

W obliczu przedstawionych argumentów pojawia się pytanie, czy łączenie małych gmin (które np. nie spełniają wymogu określonej liczby mieszkańców), powinno mieć miejsce „z urzędu”, w drodze np. ustawowej regulacji państwa? Problem ten dotyczy również tzw. gmin obwarzankowych, czyli gmin wiejskich otaczających miasta, mających swoją siedzibę na ich terenie. Przeciwko takiemu rozwiązywania problemu wypowiadają się autorzy Raportu o stanie samorządu terytorialnego w Polsce (2012), którzy uważają, że jednostka samorządu terytorialnego ma trzy zasadnicze komponenty: władzę (sprawowaną przez organy) - terytorium - ludzi. Zawężanie znaczenia podziału do kwestii finansowej (elementu władzy) to ich zdaniem błąd. Postulat łączenia gmin i jakieś minima ludnościowe, to technokratyzm, który nie bierze pod uwagę, że podział ten ma być adekwatny do struktur osadniczych - wsi, miast, aglomeracji miejskich. A te skupiska muszą tworzyć podstawę do podziału na poszczególnych poziomach, bowiem odpowiednie terytorium stwarza dopiero możliwość optymalizowania polityki, nawet przy małych środkach finansowych. Kryterium ludnościowe nie może być więc jedynym kryterium oceny danej gminy, szczególnie na terenach o niskiej gęstości zaludnienia, gdzie „większa” gmina musiałaby obejmować nieracjonalnie duży obszar, a do tego niekiedy o trudnym ukształtowaniu terenu (obszary górskie). Obowiązujący od $2011 \mathrm{r}$. art. 4c UOSG jest raczej zgodny z takim sposobem myślenia. Respektując konstytucyjną zasadę pomocniczości, państwo ułatwia zarazem łączenie, jak i dzielenie gmin, zachowując w tym względzie jednak określone reguły i kryteria, w szczególności związane z szeroko pojmowanym interesem publicznym o charakterze ogólnokrajowym ${ }^{10}$.

Podważając zatem zasadność formuły obligatoryjnego łączenia gmin według określonych kryteriów (ale utrzymując formułę wsparcia finansowego dla dobrowolnych fuzji), trzeba zwrócić uwagę na alternatywne rozwiązanie jakim jest ich współpraca w formie związków komunalnych, stowarzyszeń, umów, porozumień. W większości krajów europejskich, niezależnie od ich ustroju politycznego i administracyjnego, współpraca jednostek samorządu terytorialnego znajduje wyraz zarówno w różnorodnych formach, jakie stwarza wewnętrzne prawo tych krajów, jak i w codziennej, mniej sformalizowanej

${ }^{10}$ W 2009 r. Trybunał Konstytucyjny stwierdził w swoim uzasadnieniu, że zarówno ,[...] z punktu widzenia art. 163 Konstytucji, jak też art. 3 Europejskiej Karty Samorządu Lokalnego, w świetle dotychczasowego orzecznictwa Trybunału Konstytucyjnego, nie ulega wątpliwości, że stabilność istnienia konkretnych jednostek samorządu terytorialnego w konkretnych granicach nie jest wartością przeważającą nad racjami interesu publicznego o charakterze ogólnokrajowym; w praktyce często dochodzi do konfrontacji interesów poszczególnych gmin z interesem publicznym" (Uzasadnienie do Wyroku TK z 8.04.2009 r., za Sobota, Jawecki, Tokarczyk-Dorociak, 2012). 
praktyce (Kaczmarek, 2005). Kooperację jednostek administracyjnych uważa się za niezbędny element ich sprawnego funkcjonowania, tak pod względem organizacyjnym, jak i gospodarczym i społecznym. Współdziałanie stało się zadaniem administracji publicznej samym w sobie i choć w ustawodawstwie polskim ma charakter jedynie fakultatywny, w praktyce powinno stać się koniecznością i normą. Pozytywne doświadczenia współpracy skłaniają do opinii, że odpowiednio realizowana kooperacja między gminami może stanowić nie tylko uzupełnienie, ale także alternatywę dla reform administracyjno-terytorialnych (zob. Kaczmarek, Mikuła, 2007). Instytucja współdziałania międzyterytorialnego jest współcześnie oceniana jako wyraz elastyczności funkcjonowania systemu administracji publicznej. Jak stwierdza Delcamp (1997, s. 91) „współpraca jest odpowiedzią, jaką stara się dać bądź państwo, bądź struktury pośrednie, albo też same społeczności lokalne na nieadekwatność instytucji do realiów ekonomicznych i społecznych".

Zasadnicza konkluzja wynikająca z powyższych analiz jest następująca: administracja publiczna powinna zmieniać się $\mathrm{w}$ relacji do rozwoju procesów politycznych, gospodarczych i społecznych. Wzrost efektywności zarządzania publicznego rodzi konieczność racjonalizacji struktur terytorialnych, większej elastyczności przepisów prawnych (np. dotyczących współdziałania jednostek samorządowych) i tworzenia ram terytorialnych, odpowiadających nowym układom przestrzenno-funkcjonalnym. Wyżej wymieniona racjonalizacja nie musi być związana z kolejną dużą reformą terytorialno-administracyjną. Jednym z podstawowych warunków dobrego funkcjonowania układu terytorialnego jest jego stabilność, co nie wyklucza jednak korekt i modyfikacji istniejącej organizacji terytorialnej gmin.

Struktury terytorialne, nawet jeśli stanowią sztywny „gorset”, w którym samorządy terytorialne wypełniają - nie zawsze dostosowane do ich rozmiarów - zadania publiczne, powinny podlegać także ewolucyjnym, elastycznym zmianom. Dlatego też należy umożliwić prawne możliwości, czy też warianty realizacji zadań w innych układach przestrzennych, uzupełniających podział zasadniczy i wykorzystujących różnego rodzaju formy współdziałania i kooperacji międzyterytorialnej. Elastyczne, tworzone ad hoc, ramy terytorialne mogą służyć bieżącej realizacji zadań (np. centra usług wspólnych), nie spełniając wymogów ani trwałości, ani stabilności struktur terytorialnych (jak w przypadku podziału zasadniczego). Uwzględnianie w przepisach prawnych możliwości kreacji oddolnych jednostek terytorialnych, stanowi wyraz decentralizacji administracji i zaufania dla samorządów terytorialnych.

\section{Bibliografia}

Boddy M. (1987), Review of the new management of local government by John Stewart, „Local Government Studies", vol. 13, nr 4, s. 95-97.

Chojnicki Z., Czyż T. (2000), Nowa organizacja terytorialna Polski i uktad regionalny, „Czasopismo Geograficzne", nr 3-4.

Consolidation or fragmentation? The size of local government in Central and Eastern Europe (2002), w: Local Government and Public Service Reform Initiative, red. P. Swianiewicz, Open Society Institute, Budapest.

Delcamp A. (1997), La coopération intercommunale en Europe, w: L'intercommunalité - bilans et perspectives, PUF, Paris. 
Elżanowski M. (1982), Przesłanki reform podziału terytorialnego, Wydawnictwo Uniwersytetu Warszawskiego, Warszawa.

Gustafsson A. (1992), Samorzqd terytorialny w Szwecji, Fundacja Rozwoju Demokracji Lokalnej, Szczecin.

Henkel G. (1992), Großgemeinden oder Ämter in den neuen Bundesländern. Was dient der ländlichen Entwicklung?, „Essener Geographische Arbeiten”, Bd. 24, Paderborn, s. 81-90.

Henkel G., Tiggeman R. (1990), Kommunale Gebietsreform - Bilanzen und Bewertungen, „Essener Geographische Arbeiten", Bd. 19. Paderborn.

Hoffmann K., Jacob J. (1980), Raumordnungspolitische Bestimmungsfaktoren und Auswirkungen der kommunalen Neugliederung, w: Lokale Politik zwischen Eigenständigkeit und staatlicher Abhängigkeit. Empirische analysen zu Handlungsspielräumen, Gebietsreformen und zur Selbstverwaltung, red. H. Zieliński, „Sozialwissenschaftliche Studien zur Stadt- und Regionalpolitik", Bd. 13, s. 48-73.

Izdebski H. (2009), Samorzą terytorialny. Podstawy ustroju i dziatalności, LexisNexis, Warszawa.

Jarczewski W. (2002), Odzyskana niezależność. Przyczyny i skutki powstania nowych gmin na obrzeżach GOP w latach 90., Wydawnictwo Dante, Kraków.

Jones G., Stewart J. (1983), The case of local government, Allen\&Unwin, London.

Kaczmarek T. (2001), Reforma terytorialno-administracyjna Polski-porównanie z krajami Unii Europejskiej, w: Zróżnicowanie społeczno-gospodarcze w nowym układzie terytorialnym Polski, red. T. Czyż,. Biuletyn KPZK PAN, z. 197.

Kaczmarek T. (2005), Struktury terytorialno-administracyjne $i$ ich reformy $w$ krajach europejskich, Wydawnictwo Naukowe UAM, Poznań.

Kaczmarek T, Mikuła Ł. (2007), Ustroje terytorialno-administracyjne obszarów metropolitalnych w krajach europejskich, Bogucki Wydawnictwo Naukowe, Poznań.

Karliński W., Nelicki A., Płoskonka J. (2000), Polska powiatowa w roku 1999 - ogólna charakterysty$k a$, ,Samorząd Terytorialny”, nr 9.

Keating M. (1995), Size, efficiency and democracy: Consolidation, fragmentation and public choice, w: Theories of urban politics, red. D. Judge, G. Stoker, H. Wolman, London, s. 117-134.

Kulesza M. (1997), Reforma podziału administracyjnego Polski, w: Wartości podstawowe samorzadu terytorialnego i demokracji lokalnej, red. P. Swianiewicz, Municipium, Warszawa, s. $240-252$.

Miszczuk A. (2003), Regionalizacja administracyjna III Rzeczpospolitej. Koncepcje teoretyczne a rzeczywistość, Wydawnictwo Uniwersytetu Marii Curie-Skłodowskiej, Lublin.

Mouritzen P. E. (1989), City size and citizen's satisfactions: two competing theories revisited, „European Journal of Political Research" 17, s. 661-688.

Niskanen W. (1973), Bureaucracy - servant or master?, Institute for Economic Affairs, London.

Ocena nowego zasadniczego podziału terytorialnego państwa (2001), „Samorząd Terytorialny”, nr 4, red. G. Gorzelak, B. Jałowiecki, M. Stec, Wydawnictwo Naukowe Scholar, Warszawa.

Ocena sytuacji samorzqdów lokalnych (2013), Ministerstwo Administracji i Cyfryzacji, Warszawa.

Oitmaa K., Roigas A. (2001), Territory and administration in Europe. Community and town want to amalgamate, www.ngonet.ee, 5.07.2004.

Pirie M. (1983), Economy and local government, in: Economy and local government, red. E. Butler, M. Pirie, Adam Smith Institute, London.

Raport o stanie samorzadności terytorialnej w Polsce (2013), red. J. Hausner, Uniwersytet Ekonomiczny w Krakowie. Małopolska Szkoła Administracji Publicznej, Kraków.

Schumacher E. F. (1975), Small is beautiful, Abacus, London.

Sharpe J. (1995), Summary of the debates, w: The size of municipalities, efficiency and citizen participation. Local and regional authorities in Europe, nr 56, Council of Europe Press, s. 211-213. 
Sobota M., Jawecki B., Tokarczyk-Dorociak K. (2012), Aspekty prawne zmiany granic administracyjnych gmin, Barometr Regionalny, Analizy i Prognozy, nr 4(30), Zamość.

Stoker G. (1997), Teorie samorzqdu i polityki lokalnej, w: Wartości podstawowe samorzqdu terytorialnego i demokracji lokalnej, red. P. Swianiewicz, Municipium, Warszawa, s. 16-42.

Swianiewicz P. (2000), W poszukiwaniu optymalnej wielkości, „Studia Regionalne i Lokalne”, nr 2, s. $119-132$.

Swianiewicz P. (2002), Modele samorzadu terytorialnego w krajach Europy Zachodniej oraz Środkowo-Wschodniej. Próba generalizacji, „Studia Regionalne i Lokalne”, nr 4 (10), s. 49-67.

Szmytkie R. (2009), Miasta-zlepieńce na Ślasku Dolnym i Opolskim, Instytut Geografii i Rozwoju Regionalnego Uniwersytetu Wrocławskiego, Wrocław.

Tiebout C. (1956), A pure theory of local expenditures, „Journal of Political Economy”, vol. 64, s. $416-424$.

Uchwała Senatu Rzeczypospolitej Polskiej z dnia 11 stycznia 2001 r. w sprawie oceny nowego zasadniczego podzialu terytorialnego państwa.

Ustrój terytorialny państwa a decentralizacja systemu władzy publicznej (2012), red. A. Lutrzykowski, Wydawnictwo Adam Marszałek, Toruń.

Walczak D. (2012), Konieczność zmian w podziale terytorialnym gmin, „Zeszyty Naukowe SGGW, Ekonomika i Organizacja Gospodarki Żywnościowej”, Warszawa.

\section{The municipal administrative division in the light of 25 years of local government in Poland}

\section{Summary}

This paper seeks to present the changes in Poland's territorial division and assess it at the local level (communes). The reference point is provided by the territorial reforms of other EU states, especially those with a three-tier structure, like in Poland. The basic thesis is that the territorial organization of public administration should change so as to keep up with political, economic, social and spatial processes, the latter bearing special importance for this. The paper concludes with recommendations for ways of changing local administrative structures, such as combining, or fusions of urban and rural communes.

Key words: Poland, territorial division, administrative reform, commune 